\begin{tabular}{ccc}
\hline Jurnal Pendidikan Fisika & https://journal.unismuh.ac.id/index.php/jpf \\
& DOI: 10.26618/jpf.v9i1.4764 \\
\hline & \\
\hline
\end{tabular}

\title{
The Development of Physics Students' Worksheets Based on Science Process Skills in Basic Physics Course At Flores University
}

\author{
Yasinta Embu Ika*, Hamsa Doa \\ Program Studi Pendidikan Fisika, Universitas Flores, Ende, 86316, Indonesia \\ *Corresponding author: sinta83ika@gmail.com
}

Received: December 18, 2020; Accepted: January 10, 2021; Published: January 29, 2021

\begin{abstract}
This study aims to determine the feasibility level of physics worksheets and to figure out the increase on student's understanding after using the physics worksheets based on science process skills. This study is a development research employing ADDIE development model which consists of five stages, namely: analysis, design, development, and implementation. The design of this study was One Group Pretest-Posttest Design. The instruments used were validity assessment sheet, feasibility assessment sheet, questionnaire about the students' response toward the worksheets based on science process skills, and assessment of science process skills. the data were analyzed by using percentage of agreement $(R)$, and $N$-gain $(<g>)$. The results showed that the physics students' worksheet based on science process skills was feasible and could be used in learning as the feasibility level reached 97\%. The students' understanding of fluid material gained through working with the worksheets can improve students' science process skills both at the basic level and at the integrated level. This is proven by the results of the initial test or pre-test which indicate that the students' science process skills affected the learning outcomes obtained in which $62.25 \%$ of students' scores were in good category and $35.75 \%$ of students' scores were in fair category. Meanwhile, in the final test or post-test of students' science process skills, it was obtained that $74.50 \%$ of students' scores were in very good category and $25.50 \%$ of students' scores were in the fair category. This means that there is an increase by $0.7 \%$ in students' science process skills when using the students' worksheets.
\end{abstract}

Keywords: basic physics, physics students' worksheet, science process skills

() 2021 Physics Education Department, Universitas Muhammadiyah Makassar, Indonesia.

\section{INTRODUCTION}

Science and technology continues to develop as time goes on and it has affected the education world in a way that it demands better students' quality. Therefore, as a response to the development of science and knowledge, education as a fundamental part of life must be reformed through the curriculum and learning paradigm.

The learning paradigm emphasizes student activeness in learning, so that students are required to be independent. One of the factors that support student's independence in learning is the availability of adequate 
learning resources. Textbooks are one of the learning resources used by students to find information about the material being studied, but their existence does not fully support students' understanding of the course material being studied (Rahmi et al., 2014).

Basic physics is one of the compulsory subjects and is included in supporting science and technology course for students of physics education study program at Flores University with 3 credits. In addition to textbooks, learning physics requires student worksheets to support the success of the learning process.

Students' worksheet (LKM) is one of the learning tools that must be used in physics learning activities. One of the cores is the process whereby problem-solving procedures through scientific methods can be carried out using the worksheets.

Based on the preliminary study, it is known that the curriculum documents that are currently owned by lecturers are still limited to the syllabus and semester lecture plans (RPS) for courses. Other curriculum documents such as student worksheets (LKM) are still not available, especially those guided by certain learning models, so that they become a separate obstacle in efforts to achieve predetermined competencies.

The efforts made by lecturers so far are applying learning methods through discussion and question and answer techniques in the classroom as well as giving individual and group assignments to students. Those repeated activities create a monotonous learning pattern and most likely not suitable with either the characteristics of the material or the characteristics of students. One of the ways to overcome this problem is to develop a student worksheet that is tailored to the teaching material and student's characteristics so that it does not only empower cognitive knowledge, but also can develop science process skills competencies and students' attitudes.

Science process skills are the skills that involve thinking skills, manually and socially. Science process skills in the development of this physics worksheets require students to think both through cognitive thinking manually such as using tools and measuring, and socially through interactions such as discussion or question and answer. The worksheets based on science process skills that are developed require students to actively participate in learning process, and to be independent, responsible, and disciplined. Science process skills are a set of skills that scientists use in conducting scientific investigations (Mahmudah et al., 2019). Science process skills consist of basic process skills and integrated process skills.

Science process skills are a series of events that must be carried out by students in researching and processing findings in an experiment. According to Semiawan (Ika, 2017), scientific process skills are physical and mental skills used to discover and develop scientific facts and concepts by yourself and to foster and develop attitudes 
and values required in learning objectives. From the above opinion it can be concluded that science process skills are the ability of students to apply scientific methods in understanding, developing and discovering knowledge so that science process skills are very important for students as a provision to use scientific methods in developing science and acquiring new knowledge.

Based on the description above, in an effort to improve student understanding after using a physics worksheet based on science process skills, the researcher was interested in conducting a research entitled "development of physics students' worksheet based on science process skills in basic physics course at Flores University."

This study is intended to examine how feasible the Science process skills-based worksheets is in the basic physics course of physics education study program at Flores University. In accordance with the formulation of the problem, this study aims to develop a physics students' worksheets based on proper science process skills (valid, practical and effective) to be used for students of the physics education program at the Flores University.

\section{METHODS}

This study is a development research employing ADDIE development model. The ADDIE instructional model is an instructional process consisting of five stages, namely: the analysis stage, the design stage, the development stage, the implementation stage and the evaluation stage (Arofah, 2019).

The population in this study were all semester I students of the physics education study program at the Flores University in the academic year of 2019/2020, who include basic physics courses in their semester programs. Class A 2019/2020 was designated as a sample using saturated sampling technique (Sudijono, 2008). The research was conducted in the physics education study program at the Flores University, Ende district, East Nusa Tenggara.

The research design used was the one group pretest-posttest design. The instrument used was assessment sheet of validity and feasibility of the physics worksheet and questionnaire on the responses of physics students to the science process skills-based worksheet.

Data collection methods used in this study were validation, observation, questionnaires and learning outcomes tests. Validation was used to determine the feasibility of the worksheet that will be used in learning; observation was conducted to find out the implementation of learning, students' activities, and obstacles that occurred during learning; questionnaires used in the study were a product validity questionnaire and a student response questionnaire (using a Likert scale by giving a check mark on the available answer options); 
and tests were given to students after learning using the developed students worksheets. The post-test is given to measure the effectiveness of the worksheets being developed.

Data on the feasibility of physics worksheets and students' responses were analyzed qualitatively using a percentage. Meanwhile, to find out the increase in the students' outcomes; the scores were analyzed using the gain test to provide the percentage.

\section{RESULTS AND DISCUSSION}

The results of the preparation of worksheets based on science process skills in basic physics courses using the ADDIE Model development model (Analysis, Design, Development, Implementation, Evaluation). The following are the results of the development of a physics LKM based on science process skills based on the ADDIE model stages.

\section{A. The analysis stage}

Analysis is an identifier of the relationship between the statement and the concept needed (Hidayati \& Kurniati, 2018). At this stage two analyzes were carried out, namely performance analysis and needs analysis. In the performance analysis stage, the material to be described in this LKM is detailed, namely static and dynamic fluid material. In the section on static fluids, the materials described are: 1) hydrostatic pressure, 2) Pascal's law, 3) Archimedes' law and 4) surface tension. In the dynamic fluid section, the material described is: 1) the definition of dynamic fluid, 2) the continuity equation, and 3) Bernouli's law. The needs analysis stage shows that teaching materials are still needed to create effective and efficient learning. In this Basic Physics course, the teaching material needed is in the form of student worksheets (LKM).

\section{B. Design stage}

There are several components in this science process skills-based LKM, namely cover, concept maps, instructions for using LKM, learning activities that refer to the steps of science process skills, material summaries, practice questions, and bibliography.

\section{Development stage}

Furthermore, at the development stage, the developed LKM is tested for validity. The validity test is carried out by material expert validators and technology expert validators. The following is the result of testing the validity of the LKM based on science process skills and the feasibility of the LKM.

\section{The validity of the students' worksheet}

The worksheets validation is included in the development stage of the ADDIE model. The validity of the physics worksheets is generally carried out using expert validation which include four components, namely content feasibility, model integration (process skills approach), language, and presentation. The score of the validation assessment for each aspect of each component will be calculated 
by using a Likert scale. The results of the worksheet can be seen in the table below: validity of the process skills-based physics

Table 1. Results of validity test of the students' worksheet

\begin{tabular}{lcccc}
\hline Expert & Content & Integration & language & Display \\
\hline I & 5.0 & 5.0 & 4.6 & 3.1 \\
II & 4.8 & 5.0 & 3.6 & 3.3 \\
Average & 4.9 & 5.0 & 4.1 & 3.2 \\
\hline
\end{tabular}

Based on the data in the Table 1 above, the highest assessment component is the integration of the model (5.0 or very good), while the lowest assessment component is presentation (3.2 or sufficient). The overall average rating of the students' worksheet was 4.01 (good category).

Overall, the validation results from two experts showed that the science process skills-based physics students' worksheets can be used with several improvements needed.

2. The feasibility of the students' worksheets

After making some revision on the worksheet based on the expert validators' suggestions, the worksheet was then tried out in a small-scale trial. The small-scale trial consisted of readability and feasibility test. The readability test was given to 16 students in order to find out whether the physics worksheet was easy to understand or not. The results of the readability test analysis showed that the worksheet was easily understood by students. Meanwhile, the feasibility test was given to 4 respondents ( 2 expert lecturers and 2 lecturers who teach basic physics courses) to determine whether the worksheet is feasible enough to be used as a learning guide.

From the results of data analysis, the presentation of the feasibility of the worksheet was $97 \%$ viewed from the 5 aspects and 14 indicators developed, meaning that the physics students' worksheet based on process skills particularly in fluid material was categorized 'very feasible' to use. The analysis results can be seen in Table 2 .

Table 2. Data analysis of the worksheet feasibility

\begin{tabular}{|c|c|c|c|c|}
\hline \multirow{2}{*}{ No } & \multirow{2}{*}{ Aspect } & \multicolumn{2}{|c|}{ Score } & \multirow{2}{*}{ Reliability } \\
\hline & & $\mathrm{R} 1$ & R2 & \\
\hline 1 & $\begin{array}{l}\text { Content } \\
\text { feasibility }\end{array}$ & 3.70 & 4.00 & $96 \%$ \\
\hline \multirow[t]{2}{*}{2} & science & & & \\
\hline & $\begin{array}{l}\text { Process } \\
\text { skills }\end{array}$ & 3.80 & 3.50 & $97 \%$ \\
\hline 3 & Language & 3.50 & 3.80 & $97 \%$ \\
\hline 4 & $\begin{array}{l}\text { Sophisticati } \\
\text { on/novelty }\end{array}$ & 3.00 & 3.00 & $100 \%$ \\
\hline 5 & Display & 3.30 & 4.00 & $95 \%$ \\
\hline \multicolumn{2}{|c|}{ Score average } & 3.40 & 3.60 & $97 \%$ \\
\hline \multicolumn{2}{|c|}{ Criteria } & \multicolumn{3}{|c|}{ Very feasible } \\
\hline
\end{tabular}

Based on table 2 above, the reliability of the content feasibility aspect reached the agreement of $96 \%$, the science process skill aspect obtained $97 \%$ agreement percentage, the linguistic aspect obtained $97 \%$ agreement percentage, the sophistication aspect obtained 
$100 \%$ agreement percentage, and the display aspect obtained the agreement of $95 \%$. Therefore, the average score of all aspects was $97 \%$ agreement. The feasibility diagram of the physics students' worksheet based on science process skills is presented in the following figure.

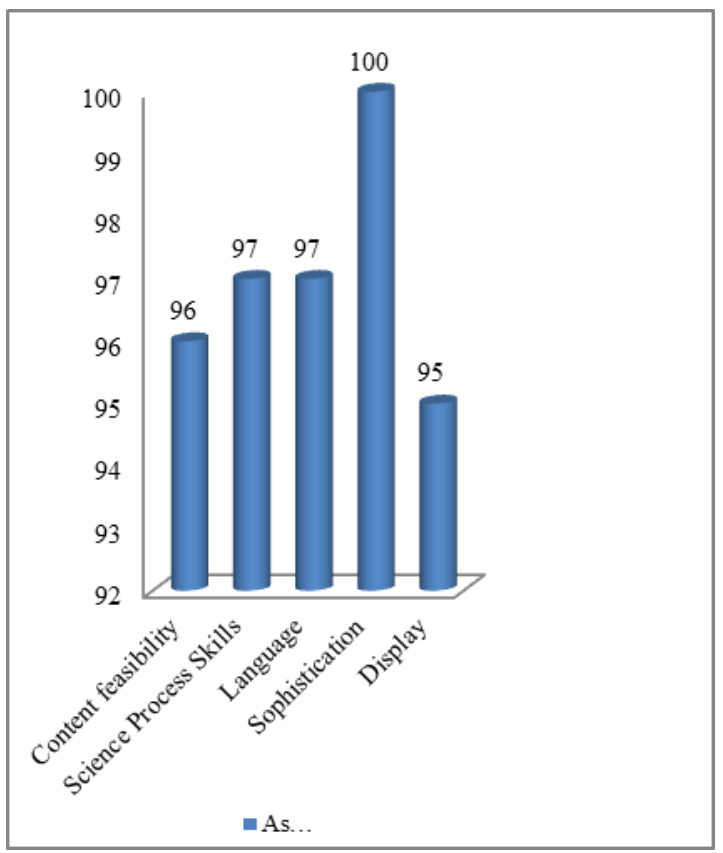

Figure 1. Diagram of worksheet feasibility

Based on the worksheet feasibility diagram in Figure 1 above, it is known that the average agreement percentage score of all aspects was $97 \%$. Thus, the worksheet was categorized very feasible. This is due to the presentation of the worksheet material which is very suitable with the learning outcomes of the study program and the learning outcomes of the course. The presentation of the physics LKM material also takes into account the principles of relevance, consistency, and adequacy as recommended by the Ministry of National Education (2008). The results of this study are in line with Prastowo's research
(2015) which states that worksheets can be used as teaching materials that facilitate the implementation of learning, reduce the role of teachers, enable students to learn independently and make material easier to understand by students.

\section{Implementation stage}

LKM physics based on science process skills is then applied or used in learning basic physics courses on fluid material. This LKM is given to class II A students of the physics education study program, totaling 16 people. After obtaining learning using LKM based on science process skills, students are given a questionnaire to capture student responses to the LKM.

\section{E. Evaluation stage}

The evaluation stage in this study was carried out from the beginning of development. Starting from the analysis stage to the implementation stage. Evaluation is carried out by making improvements according to validator suggestions and student responses. The evaluation of the effectiveness of using science process skills-based LKM was carried out by testing student science process skills and understanding.

The effectiveness of student worksheets (LKM) is the final stage of the ADDIE model, which is included in the evaluation stage. At this stage, students were given a test to determine the student's science process skills and a questionnaire to determine the 
student's response to the designed physics worksheet.

\section{Student response}

The physics worksheet is suitable for use in student learning. Based on the results of the analysis of student responses to the development of physics worksheet, students responded very positively. The analysis of the students' response questionnaire can be seen in Table 3 below.

Table 3. Data of students' responses

\begin{tabular}{|c|c|c|c|}
\hline No & Questions & $\begin{array}{c}\text { Students' } \\
\text { response } \\
(\%)\end{array}$ & $\begin{array}{c}\text { Categ } \\
\text { ory }\end{array}$ \\
\hline 1 & \multicolumn{3}{|c|}{$\begin{array}{l}\text { What do you think about the following } \\
\text { aspect: }\end{array}$} \\
\hline $\mathrm{a}$ & $\begin{array}{l}\text { Leaning } \\
\text { material/content }\end{array}$ & 96 & $\begin{array}{l}\text { Very } \\
\text { strong }\end{array}$ \\
\hline $\mathrm{b}$ & Student textbook & 94 & $\begin{array}{l}\text { Very } \\
\text { strong }\end{array}$ \\
\hline c & Student worksheet & 76 & Strong \\
\hline d & Learning atmosphere & 89 & $\begin{array}{l}\text { Very } \\
\text { strong }\end{array}$ \\
\hline $\mathrm{e}$ & Teaching method & 75 & Strong \\
\hline & Score average & 86 & $\begin{array}{l}\text { Very } \\
\text { strong }\end{array}$ \\
\hline 2 & \multicolumn{3}{|c|}{ Do you feel new to the following aspect? } \\
\hline $\mathrm{a}$ & $\begin{array}{l}\text { Leaning } \\
\text { material/content }\end{array}$ & 74 & Strong \\
\hline $\mathrm{b}$ & Student textbook & 93 & $\begin{array}{l}\text { Very } \\
\text { strong }\end{array}$ \\
\hline $\mathrm{c}$ & Student worksheet & 87 & $\begin{array}{l}\text { Very } \\
\text { strong }\end{array}$ \\
\hline d & Learning atmosphere & 92 & $\begin{array}{l}\text { Very } \\
\text { strong }\end{array}$ \\
\hline $\mathrm{e}$ & Teaching method & 87 & $\begin{array}{l}\text { Very } \\
\text { strong }\end{array}$ \\
\hline & Score average & 86,6 & $\begin{array}{l}\text { Very } \\
\text { strong }\end{array}$ \\
\hline 3 & \multicolumn{3}{|c|}{$\begin{array}{l}\text { Can you easily understand the following } \\
\text { aspect? }\end{array}$} \\
\hline $\mathrm{a}$ & $\begin{array}{l}\text { Language of the } \\
\text { textbook }\end{array}$ & 91 & $\begin{array}{l}\text { Very } \\
\text { strong }\end{array}$ \\
\hline $\mathrm{b}$ & $\begin{array}{l}\text { Material/content of } \\
\text { the book }\end{array}$ & 93 & $\begin{array}{l}\text { Very } \\
\text { strong }\end{array}$ \\
\hline $\mathrm{c}$ & Students worksheet & 71 & Strong \\
\hline d & Exercises & 84 & $\begin{array}{l}\text { Very } \\
\text { strong }\end{array}$ \\
\hline $\mathrm{e}$ & Teaching method & 95 & $\begin{array}{l}\text { Very } \\
\text { strong }\end{array}$ \\
\hline & Score average & 86,8 & $\begin{array}{l}\text { Very } \\
\text { strong }\end{array}$ \\
\hline
\end{tabular}

\begin{tabular}{|c|c|c|c|}
\hline 4 & What do you think if: & & \\
\hline $\mathrm{a}$ & $\begin{array}{l}\text { The next material is } \\
\text { taught this kind of } \\
\text { teaching? }\end{array}$ & 88 & $\begin{array}{l}\text { Very } \\
\text { strong }\end{array}$ \\
\hline \multirow[t]{2}{*}{$\mathrm{b}$} & $\begin{array}{l}\text { The other subjects are } \\
\text { conducted using this } \\
\text { kind of teaching? }\end{array}$ & 93 & $\begin{array}{l}\text { Very } \\
\text { strong }\end{array}$ \\
\hline & Score average & 90,5 & $\begin{array}{l}\text { Very } \\
\text { strong }\end{array}$ \\
\hline 5 & How is: & & \\
\hline $\mathrm{a}$ & $\begin{array}{l}\text { The lecturer's } \\
\text { explanation during the } \\
\text { teaching and learning } \\
\text { process? }\end{array}$ & 94 & $\begin{array}{l}\text { Very } \\
\text { strong }\end{array}$ \\
\hline \multirow[t]{2}{*}{$\mathrm{b}$} & $\begin{array}{l}\text { The lecturer's } \\
\text { guidance when doing } \\
\text { an experiment? }\end{array}$ & 88 & $\begin{array}{l}\text { Very } \\
\text { strong }\end{array}$ \\
\hline & Score average & 91 & $\begin{array}{l}\text { Very } \\
\text { strong }\end{array}$ \\
\hline 6 & \multicolumn{3}{|c|}{$\begin{array}{l}\text { What do you think about the following } \\
\text { science process skills: }\end{array}$} \\
\hline a. & \multicolumn{2}{|l|}{ Observing or reading } & \multirow{2}{*}{$\begin{array}{l}\text { Very } \\
\text { strong } \\
\text { Very } \\
\text { strong }\end{array}$} \\
\hline $\mathrm{b}$ & Formulating problems & 92 & \\
\hline $\mathrm{c}$ & $\begin{array}{l}\text { Generating } \\
\text { experiment } \\
\text { hypotheses }\end{array}$ & 70 & Strong \\
\hline $\mathrm{d}$ & $\begin{array}{l}\text { Determining } \\
\text { experiment variables }\end{array}$ & 75 & Strong \\
\hline $\mathrm{e}$ & $\begin{array}{l}\text { Designing/conducting } \\
\text { experiments }\end{array}$ & 75 & Strong \\
\hline f. & $\begin{array}{l}\text { Analyzing findings of } \\
\text { experiments }\end{array}$ & 75 & Strong \\
\hline \multirow[t]{2}{*}{$\mathrm{g}$} & $\begin{array}{l}\text { Drawing conclusions } \\
\text { of the experiments } \\
\text { results }\end{array}$ & 80 & Strong \\
\hline & Score average & 79,8 & Strong \\
\hline \multirow[t]{2}{*}{7} & Do you fee easy to: & & \\
\hline & $\begin{array}{l}\text { Answer the question } \\
\text { items of KPS test? }\end{array}$ & 96 & $\begin{array}{l}\text { Very } \\
\text { strong }\end{array}$ \\
\hline \multicolumn{2}{|c|}{ Average of students' responses } & 85 & $\begin{array}{l}\text { Very } \\
\text { strong }\end{array}$ \\
\hline
\end{tabular}

Overall, based on Table 3 above, the average students responds with very strong criteria or as much as $85 \%$ (Riduwan, 2009).

\section{Students'science process skills}

Skills refers to the ability to use thoughts, reasoning, and actions efficiently and effectively to achieve certain results, including creativity. Process is defined as the 
complex skill set scientists use in conducting scientific research. Process is also a big concept that can be broken down into components that must be mastered when doing research (Devi, 2011).

Science process skills are important for teaching ways to acquire knowledge (Nasar \& Melkyanus, 2020). Data on students' science process skills were obtained through pre-test and post-test data in the form of student worksheets on the fluid material used during practicum. In carrying out practicum, students are required to conduct experiments and write practicum reports that include aspects of science process skills. The output of science process skills based on the results of students' worksheets (LKM) are formulating hypotheses, identifying variables, analyzing data and making conclusions. The results of the process skills activities taken from practicum reports or experiments are presented in the table below.

Table 4. Analysis results of science process skills outputs (product)

\begin{tabular}{|c|c|c|}
\hline $\begin{array}{cc}\text { No } & \text { Science Process } \\
\text { Skills } \\
\end{array}$ & Average & Category \\
\hline $\begin{array}{l}1 \text { Formulating } \\
\text { hypotheses }\end{array}$ & 3.29 & Very good \\
\hline $\begin{array}{l}2 \text { Identifying } \\
\text { variables }\end{array}$ & 3.26 & Very good \\
\hline 3 Analyzing data & 2.58 & Good \\
\hline $\begin{array}{l}4 \text { Making } \\
\text { conclusions }\end{array}$ & 3.04 & Good \\
\hline Average & 3.04 & Good \\
\hline
\end{tabular}

The output of science process skills based on the results of observations conducted by 2 observers, involving the activity of arranging tools and materials, collecting data, tidying up tools and materials. The table of results of the output of science process skills (process), namely:

Table 5. Analysis results of science process skills outputs (process)

\begin{tabular}{|c|c|c|c|}
\hline No & $\begin{array}{l}\text { Conducting } \\
\text { experiments }\end{array}$ & Average & Category \\
\hline 1 & $\begin{array}{l}\text { Arranging tools } \\
\text { and materials }\end{array}$ & 3.06 & Good \\
\hline 2 & Collecting data & 3.63 & Very good \\
\hline \multirow[t]{2}{*}{3} & $\begin{array}{l}\text { Tidying up tools } \\
\text { and materials }\end{array}$ & 3.38 & Good \\
\hline & Average & 3.36 & Good \\
\hline
\end{tabular}

Based on table 4 (product) and table 5 (process) above, it can be concluded that the science process skills of students are in Good category. In addition to the achievement of science process skills, students are also given a pre-test and a post-test to determine the students' science process skills through tests. Student science process skills pre-test and post-test data can be seen in the table below.

Table 6. Pre-test and post-test data of science process skills

\begin{tabular}{lrc}
\hline \multicolumn{1}{c}{$\begin{array}{l}\text { Data } \\
\text { description }\end{array}$} & Pre- test & Post-test \\
\hline Mean & 64.25 & 74.50 \\
Maximum score & 75.00 & 85.50 \\
Minimum score & 45.50 & 50.00 \\
Deviation & 17.90 & 11.51 \\
Standard & & \\
\hline
\end{tabular}

Based on the average pre-test and posttest data in table 6 above, the N-Gain of process skills is 0.7 or high category. This is in line with (Alatas, 2018) research that revealed that virtual laboratory media can effectively improve science process skills. 


\section{Students' understanding}

Students' understanding in the teaching and learning process is very essential because it is one of the learning objectives. Assessment of students' understanding of learning is also important to determine the extent to which students' ability is to accept and understand the learning material being taught. Understanding and mastery of a concept is a prerequisite for mastering the next material or concept (Rahmawati, 2020).

The use of physics worksheets in fluid material implementation can improve students' science process skills both at the basic level and at the integrated level. Based on the results of the initial test or pre-test, the science process skills affected the students' learning outcomes in which $62.25 \%$ of students' scores were in very good category and $35.75 \%$ of students' scores were in fair category. Meanwhile, in the final test or posttest of students' science process skills, it was obtained that $74.50 \%$ of students' scores were in very good category and $25.50 \%$ of students' scores were in the fair category. This means that there is an increase by $0.7 \%$ in students' science process skills when using the students' worksheets

\section{CONCLUSION AND SUGGESTION}

\section{A. Conclusion}

Based on the results of the analysis and discussion, it can be concluded that: the science process skills-based physics worksheet is feasible and can be used in learning. Meanwhile, student understanding of fluid material through the implementation of the worksheet can improve students' science process skills both at the basic level and at the integrated level.

This is proven by the results of the initial test or pre-test which indicate that the students' science process skills affected the learning outcomes obtained in which $62.25 \%$ of students' scores were in good category and $35.75 \%$ of students' scores were in fair category. Meanwhile, in the final test or posttest of students' science process skills, it was obtained that $74.50 \%$ of students' scores were in very good category and $25.50 \%$ of students' scores were in the fair category. This means that there is an increase by $0.7 \%$ in students' science process skills when using the students' worksheets.

\section{B. Suggestions}

The application of physics students' worksheets based on science process skills in learning is undeniably good, but lecturers must be able to manage time during learning so that learning can run more effectively and efficiently. It is recommended that further researchers provide a clear picture to students about science process skills-based learning. In addition, the physics students' worksheet used during learning is better distributed to students before the learning is carried out so that students can understand the worksheet more easily. 


\section{ACKNOWLEDGMENTS}

Acknowledgments are addressed to:

1. DPRM Dikti for the year of 2020 which is willing to fund this research as evidenced by a research contract letter between the head of LPPM University of Flores and the head of research executor No. 87/115 / F12 / N / 2020

2. Institute for Research and Community Service, University of Flores which is willing to give permission to conduct research which is proven by a permit No. 36/115 / F12 / N / 2020

3. The National Unity, Political and Community Protection Agency of the Ende Regency government which is willing to provide recommendations to conduct this research which is proven by a certificate No. BKPPM. 423 / IV / 02 / IV / 2020.

\section{REFERENCES}

Alatas, F. (2018). Peningkatan keterampilan proses sains mahasiswa menggunakan media laboratorium virtual pada matakuliah termodinamika. Jurnal Pendidikan Fisika, 6(3), 269-278. https://journal.unismuh.ac.id/index.php /jpf/article/view/1434

Apriyani, D. C. N., \& Suminar, E. P. W. (2016). Pengembangan LKM pada materi kuliah struktur aljabar untuk mahasiswa STKIP PGRI Pacitan. Jurnal Humaniora, 4(1), 10-473. http://ejournal.stkippacitan.ac.id/index. $\mathrm{php} / \mathrm{jh} /$ article/view/24
Arifin, Z. (2009) Evaluasi pembelajaran (prinsip, teknik, prosedur). Bandung: Remaja Rosdakarya.

Arofah, R. H. C. (2019) Pengembangan bahan ajar berbasis ADDIE model. Education Journal, 3(1), 35-42. http://ojs.umsida.ac.id/index.php/halaq a/article/view/2124

Damayanti, D. S., Ngazizah, N., \& Kurniawan, E. S. (2012). Pengembangan LKS dengan pendekatan inkuiri teribimbing untuk mengoptimalkan kemampuan berpikir kritis peserta didik pada materi listrik dinamis SMA N 3 Purworejo kelas X". Jurnal Radiasi. 2(1).

http://jurnal.umpwr.ac.id/index.php/rad iasi/article/view/516

Depdikbud. (2013). Buku guru ilmu pengetahuan alam SMP/Mts kelas VIII. Jakarta: Kementrian Pendidikan dan Kebudayaan.

Devi, K. P. (2011). Pendekatan Keterampilan Proses pada Pembelajaran IPA. (http://www.bpptkpujabar.com/materi/ 0109 SMA 05.pdf)

Widoyoko, E. P. (2009). Evaluasi Program Pembelajaran. Yogyakarta: Pustaka Belajar.

Hidayati, D. W., \& Kurniati, L. (2018).The Influence of Self Regulated Learning to Mathematics Critical Thinking Ability On 3D-Shapes Geometry Learning Using Geogebra. JIPM (Jurnal Ilmiah Pendidikan Matematika), 7(1), 40-48. http://ejournal.unipma.ac.id/index.php/jipm/art icle/view/2965

Ika, Y. E., Madlazim, \& Ibrahim, M. (2017). pengembangan perangkat pembelajaran inkuiri terbimbing menggunakan software visual analyzer (VA) untuk melatihkan keterampilan proses sains siswa. Jurnal 
Ilmiah Dinamika Sains. 1(1): 58-70. http://ejournal.uniflor.ac.id/index.php/o ptika/article/view/130

Ika, Y. E. \& Ana S. R. (2019). Pengembangan LKS pada materi cahaya dan alat optik dengan model inquiry berbasis karakter untuk siswa SMP. Jurnal Inovasi Pendidikan Fisika dan Riset Ilmiah. 3(02),62-69.

http://journal.stkipnurulhuda.ac.id/inde x.php/JIPFRI/article/view/532

Lepiyanto, A. (2014). Analisis keterampilan proses sains pada pembelajaran berbasis praktikum. Bio Edukasi. 5(2), 156-161.

https://ojs.fkip.ummetro.ac.id/index.ph $\mathrm{p} /$ biologi/article/view/795

Lestari, M. Y. \& Nirva D. (2018). Keterampilan proses sains pada pelaksanaan praktikum fisika dasar I. Jurnal Indonesian of Science and Mathematics Education, 1(1), 49-54. http://ejournal.radenintan.ac.id/index.p hp/IJSME/article/view/2474

Mahmudah, I. R., Makiyah, Y. S., \& Sulistyaningsih, D. (2019). Profil keterampilan proses sains (KPS) siswa SMA di kota Bandung. Diffraction, 1 (1), 39-43.

http://jurnal.unsil.ac.id/index.php/Diffra ction/article/view/808

Nasar, A. \& Melkyanus B. U. K. (2020). Effectiveness of experimental laboratory methods on understanding the concept of light, science processes skills, and scientific attitudes of students. Jurnal Pendidikan Fisika, 7 (3), 262-270.

https://journal.unismuh.ac.id/index.php /ipf/article/view/2333

Prastowo, A. (2011). Panduan kreatif membuat bahan ajar inovatif. Yogyakarta: Diva Press
Rahmawati, M., Uswatun, D. A., \& Maula, L. H. (2020). Analisis pemahaman konsep matematis siswa berdasarkan teori apos melalui soal open ended berbasis daring di kelas tinggi sekolah dasar. Didaktik: jurnal Ilmiah PGSD STKIP Subang, 6(1), 155-165.

https://journal.stkipsubang.ac.id/index. php/didaktik/article/view/122

Rahmatillah, Halim. A., \& Hasan, M. (2017). Pengembangan lembar kerja peserta didik berbasis keterampilan proses sains terhadap aktivitas pada materi koloid. Jurnal IPA dan Pembelajaran IPA. 1(2), 121-130.

http://jurnal.unsyiah.ac.id/JIPI/article/vi ew/9686

Rahmi, V. A., \& Melisa. (2014). Pengembangan lembar kerja mahasiswa berbasis problem based learning pada perkuliahan persamaan diferensial biasa. Prosiding Seminar Nasional dan Pendidikan Sains IX. Vol. 5, No. 1, ISSN:2087-0922

Rokhimawan, M. A. (2016). Pengembangan LKM berbasis keterampilan proses sains pada mata kuliah pembelajaran IPA MI 1. Jurnal Pendidikan Islam. 8(1), 1-11. http://jurnal.albidayah.id/index.php/ho me/article/view/88

Rustaman, A. (2014). Membangun literasi sains peserta didik. Bandung: Humaniora.

Sudijono, A. (2008). Pengantar statistik pendidikan. Jakarta: Raja Grafindo Persada.

Trianto. (2011). Model-model pembelajaran inovatif berorientasi konstruktivisme. Jakarta: Prestasi Pustaka. 